ppi $201502 Z U 4645$

Esta publicación cientifica en formato digital es continuidad de la revista impresa ISSN-Versión Impresa 0798-1406 / ISSN-Versión on line 2542-3185Depósito legal pp

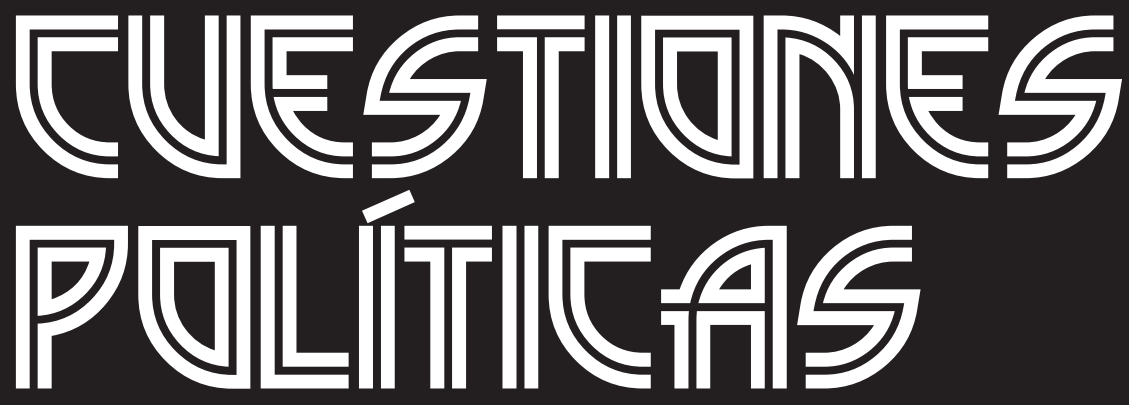

Instituto de Estudios Políticos y Derecho Público "Dr. Humberto J. La Roche' de la Facultad de Ciencias Jurídicas y Políticas de la Universidad del Zulia Maracaibo, Venezuela
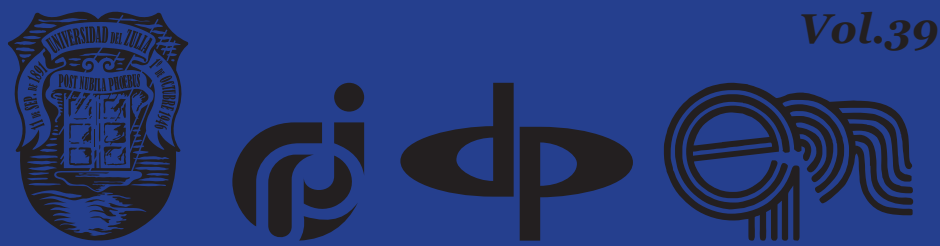


\title{
Special Confiscation as a Measure of Criminal Law under Ukrainian Legislation
}

\author{
DOI: https://doi.org/10.46398/cuestpol.3968.54
}

\author{
Tetiana Nikolaienko * \\ Viktoria Babanina ** \\ Tetiana Bohdanevych ***
}

\begin{abstract}
Through a documentary methodology the article is devoted to the study of special confiscation as a measure of criminal law, which was introduced in Ukrainian legislation on the path of transformation and reform in the institution of confiscation of property. The study found that the emergence of a special forfeiture was mainly dictated by Ukraine's choice of European integration and the need to fulfil its obligations to bring domestic criminal law into line with European standards and international legal practice in the fight against crime. The article discusses the provisions of criminal law on the regulation of special confiscation as another measure of criminal law and considers the main problematic aspects of this institution in the doctrine of Ukrainian criminal law. The correlation between general confiscation and special confiscation was revealed in the article. It was concluded that these two types of seizures are different in a legal nature. The confiscation of property is a type of additional punishment and, the special confiscation of property is an independent type of other measures of
\end{abstract} the nature of criminal law.

Keywords: confiscation; confiscation of property; property rights; criminal law in Ukraine; crime.

Lieutenant-colonel of justice, Doctor of Sciences in Law, Associate Professor, Professor of the Criminal Law and Criminal Procedure Department of the National Academy of the State Border Guard Service of Ukraine named after Bohdan Khmelnytskyi, Khmelnytskyi, Ukraine. ORCID ID: https://orcid. org/oooo-0002-4587-2561.

** Professor of Criminal Law Department of the National Academy of Internal Affairs, PhD in Law, Associate Professor, Kyiv, Ukraine, ORCID ID: https://orcid.org/ORCID/oooo-0003-4173-488X.

*** Leading Researcher of the National School of Judges of Ukraine, Kyiv, Ukraine. ORCID ID: https:// orcid.org/oooo-0002-0669-2517. 


\section{Decomiso especial como medida de derecho penal en la legislación ucraniana}

\section{Resumen}

Mediante una metodología documental el artículo se dedica al estudio de la confiscación especial como medida de derecho penal, que se introdujo en la legislación de Ucrania sobre el camino de la transformación y la reforma en la institución de confiscación de bienes. El estudio encontró que la aparición de un decomiso especial estaba dictada principalmente por la elección de Ucrania de la integración europea y la necesidad de cumplir con sus obligaciones de poner el derecho penal interno en consonancia con las normas europeas y la práctica jurídica internacional en la lucha contra la delincuencia. El artículo analiza las disposiciones de la legislación penal sobre la regulación del decomiso especial como otra medida del derecho penal y considera los principales aspectos problemáticos de esta institución en la doctrina del derecho penal de Ucrania. La correlación entre la confiscación general y el decomiso especial se reveló en el artículo. Se concluyó que estos dos tipos de decomisos son diferentes en naturaleza jurídica. La confiscación de bienes es un tipo de castigo adicional y, la confiscación especial de bienes es un tipo independiente de otras medidas de naturaleza de derecho penal.

Palabras clave: decomiso especial; confiscación de bienes; derechos de propiedad, derecho penal en Ucrania; crimen.

\section{Introduction}

In accordance with the basic principle of protection of property rights, enshrined in Art. 41 of the Constitution of Ukraine, everyone has the right to own, use and dispose of their property and no one can be unlawfully deprived of property rights. However, Ukrainian law allows for the restriction of property rights if the interests of society or the state require such a restriction. It is allowed, in particular, by confiscation of property (Part 6 of Article 41 of the Constitution of Ukraine, 1996). Thus, recognizing the importance of the development of property relations, the legislator, however, clearly and unequivocally recognizes the right of the state to intervene in these relations within certain limits.

One of the main conditions for Ukraine's membership in the EU is the adaptation of its national legislation to the law of the European Union. Given the new threats and challenges of the modern criminal environment, the international community and some countries around the world are implementing new non-traditional measures to combat the most dangerous crimes, including confiscation. In this regard, Ukraine is obliged to create 
an effective regulatory framework and systematically improve the relevant regulations that guarantee the inviolability of property rights, as well as clearly define the limits of permissible (reasonable) state intervention in the sphere of free property ownership.

One of the measures within the framework of adaptation of the legislation of Ukraine to the law of the European Union was the introduction of the institution of special confiscation in the criminal legislation of Ukraine. Such implementation was carried out by the Law of Ukraine "On Amendments to the Criminal and Criminal Procedure Codes of Ukraine regarding the implementation of the Action Plan on visa liberalization by the European Union for Ukraine" of April 18, 2013 (Verkhovna Rada, 2014). This was definitely a positive step towards adapting domestic legislation to EU law. However, the legislation governing special confiscation is still imperfect and therefore needs additional attention.

\section{Analysis of resent research and methodology.}

The purpose of the paper is to study the legal regulation of special confiscation as another measure of criminal law, as well as to address debatable issues to determine the criminal nature of the institution of special confiscation, its place in the system of criminal law of Ukraine and peculiarities of its application.

To achieve the purpose of the paper, general and special scientific research methods were used in the study. The formal-legal method (dogmatic) was used during the legal analysis of the provisions of the Criminal Code of Ukraine, which regulate the concept of «special confiscation» and cases of its application. To establish the content of certain criminal law concepts (for example, «confiscation of property», «special confiscation», «measures of criminal law nature»), the hermeneutic method was used. When comparing domestic and foreign criminal law on the rules governing special confiscation, as well as in clarifying the similarities and differences between confiscation of property as a form of punishment and special confiscation as another measure of criminal law, the comparative legal method was used.

The historical method was used to study the patterns of origin and development of the provisions governing special confiscation in the current criminal law of Ukraine. The method of systematic analysis was used to distinguish special confiscation as another measure of criminal law nature from confiscation of property as a type of punishment. 


\section{The concept and types of confiscation under the legislation of Ukraine}

Confiscation as a type of additional punishment is used in Ukraine in administrative and criminal law. According to Art. 59 of the Criminal Code of Ukraine, confiscation of property is established for serious and especially serious mercenary crimes and may be imposed only in cases specifically provided for in the Special Part of this Code (Verkhovna Rada, 2001). According to Art. 96-6 of the Criminal Code of Ukraine, confiscation of property as an additional measure of a criminal nature may be applied to legal entities.

Confiscation as an administrative penalty is provided by Art. 24, 29 of the Administrative Code of Ukraine (Verkhovna Rada, 1984) and consists in the forced gratuitous transfer of an object that has become an instrument of commission or a direct object of an administrative offense in the ownership of the state by court decision. In this case, confiscation can be applied as a basic and additional penalty. Confiscation as an administrative sanction can be applied only to individuals. In order to confiscate property in administrative proceedings, it is necessary that such a sanction be expressly provided for in the relevant article of the Administrative Code of Ukraine, and the case be considered by a court.

Civil confiscation, sometimes called the recovery of unjustified (illegal) assets, appeared in the Civil Procedure Code of Ukraine (Verkhovna Rada, 2004) with the adoption of the Law of Ukraine "On Amendments to Certain Legislative Acts of Ukraine Concerning Ensuring the Activities of the National Anti-Corruption Bureau of Ukraine and the National Agency for the Prevention of Corruption" of February 12, 2015 (Verkhovna Rada, 2015), which provided that the claim for unfounded assets and their recovery from persons is filed in the interests of the state by the prosecutor within the statute of limitations from the date of entry into force of the conviction against a person authorized to perform state functions or Local Government.

Thus, the recognition of assets as unfounded and their recovery in favor of the state in civil proceedings is already provided by current procedural law but is possible only after establishing the guilt of a person in a crime and a court conviction in these circumstances.

The Criminal Code of Ukraine defines confiscation of property as the forced gratuitous seizure of all or part of the property that is the property of the convict (Part 1 of Article 59 of the Criminal Code of Ukraine).

Based on the legislative definition of confiscation of property (Article 59 of the Criminal Code), some scholars identify the following features of the confiscation: 
Tetiana Nikolaienko, Viktoria Babanina y Tetiana Bohdanevych
828 Special Confiscation as a Measure of Criminal Law under Ukrainian Legislation

1) forced confiscation of property in favor of the state, i.e. regardless of the will of its owner;

2) gratuitous seizure of all or part of the property by the state.

3) only the property or its part specified in the court verdict is subject to seizure.

4) is applied by the court only to the convicted person.

5) is appointed only in cases specifically provided for in the Special Part of the Criminal Code of Ukraine.

6) applies to a person who has committed a serious or particularly serious mercenary crime, or a crime against the foundations of national security of Ukraine or public security, regardless of their severity (Grigorieva and Pavlovskaya, 2014).

However, the attribution of the condition (type of crime) and the order of its appointment (if provided for in the sanction) to the signs of confiscation of property seems inexpedient, as they do not reflect the legal nature, essence of this measure as a type of punishment.

Other scholars suggest that the confiscation of property should be understood as a restriction of the convict's right to property by turning the property belonging to him or her into state ownership. Among the features that characterize it, scientists include:

1) use for committing a crime.

2) only by the court.

3) in cases specifically provided by law.

4) compulsorily.

5) restriction (termination) of the right of ownership by gratuitous application to the state property.

6) applies to property belonging to the offender on the right of ownership (Ponomarenko, 2009).

Confiscation of property is also defined as a compulsory deprivation of a person of the right of ownership of illegally owned, used or transferred property, as a sanction for the commission of a crime imposed by a court decision (Sobko, 2008). However, this definition raises some doubts, in particular the position of the author on the existence of ownership of illegally owned, used or transferred property. Signs of confiscation in this approach include: 
1) coercion.

2) free of charge.

3) active withdrawal actions.

4) directing property to state property.

5) restriction of the right of ownership due to a person on the basis of a court decision.

Confiscation of property is a type of punishment, so it has all the features that are characteristic of this measure of state coercion.

Punishment is one of the legal consequences of committing a crime. From the point of view of the guilty punishment is a consequence of the act committed by them, from the point of view of the state - a measure taken as a result of the act committed by the guilty (Tagantsev, 2001). As a socio-legal phenomenon, the concept of "punishment" is characterized by a historically changing nature. The genesis of the development of ideas about its content shows that their evolution depends entirely on society itself, its ideology, culture, morality, and choice of means of combating crime (Yushchyk, 2014). Changing the moral and legal parameters of society affects the understanding of the content of punishment, its purpose, system and types. That is why the concept of punishment must correspond to the modern living conditions of society, the existing political, economic, social relations, moral norms and values.

Thus, confiscation of property as a form of punishment is a coercive measure applied on behalf of the state by a court sentence to a person convicted of a crime. It consists in the forced deprivation of ownership of specific property acquired legally and the transfer it is owned by the state (Bidna, 2017).

Other cases of confiscation that are not criminal penalties and are therefore called special types of confiscation should be distinguished from confiscation of property as a type of criminal punishment (Skrypnyk, 2010). In accordance with Art. 96-1 of the Criminal Code of Ukraine, special confiscation consists in compulsory gratuitous seizure by court decision of state property, money and other property in cases specified by this Code, subject to the commission of a crime under Article 354 and Articles 364, 364-1, 365- 2, 368 - 369-2 of Section XVII of the Special Part of this Code, or a socially dangerous act that falls under the signs of an act provided for in these articles.

According to Art. 96-2 of the Criminal Code of Ukraine, special confiscation is applied if the money, valuables, and other property: 


\section{Tetiana Nikolaienko, Viktoria Babanina y Tetiana Bohdanevych \\ 830 Special Confiscation as a Measure of Criminal Law under Ukrainian Legislation}

1) received as a result of a crime and / or are income from such property.

2) were intended (used) to persuade a person to commit a crime, to finance and / or provide material for a crime or to be rewarded for its commission.

3) were the subject of a crime, except for those that are returned to the owner (legal owner), and in the case when it is not established become the property of the state.

4) were found, manufactured, adapted, or used as means or instruments of committing a crime, except for those returned to the owner (legal owner), who did not know and could not have known about their illegal use.

As a result of the study of various types of confiscations provided by criminal law of Ukraine as special types of criminal influence, several conclusions can be drawn.

First, today the criminal law of Ukraine regulates the following types of criminal confiscation:

1) confiscation of property as an additional punishment (Articles 52, 59 of the Criminal Code of Ukraine);

2) confiscation, which is directly defined in the sanctions of the articles of the Special Part of the Criminal Code of Ukraine - special confiscation provided for in the Special Part of the Criminal Code of Ukraine.

3) special confiscation determined by the General Part of the Criminal Code of Ukraine (Articles 96-1, 96-2 of the Criminal Code of Ukraine);

4) confiscation of property as a measure of a criminal nature against legal entities (compulsory free seizure of state property of a legal entity, which will be applied by the court in case of liquidation of a legal entity under the Criminal Code of Ukraine) (Articles 96-6, 96-8 of the Criminal Code of Ukraine).

Secondly, taking into account the system of criminal law measures developed in the criminal law of Ukraine, confiscation of property as a type of punishment is attributed to coercive punitive criminal law measures; special confiscation provided for in both the General and Special Parts of the Criminal Code of Ukraine - to coercive non-punitive other criminal measures; confiscation of property of a legal entity - to a certain type of coercive criminal measures applied to a legal entity.

Third, the analysis of the legislation of foreign states has shown that states have different approaches to determining the types of confiscation. Some recognize as punishment the general confiscation, i.e. compulsory 
gratuitous conversion in favor of the state of property belonging to the convict, which is in no way connected with the committed crime (the Republic of Belarus, the Republic of Bulgaria, the Republic of Armenia, the Republic of Kazakhstan) (Lipinsky and Musatkina, 2019). These states consider the confiscation of property to be a punishment that is applied only as an additional, it does not apply to minors. Article sanctions are set either as a mandatory or as an optional additional punishment. The criminal law of some of the considered states of this group, along with the confiscation of property as a form of punishment, also provides for special confiscation, which is not considered a punishment (Wassmer, 2019).

The legislation of the second group of states allows only special confiscation as punishment - forced gratuitous confiscation of specific types of property determined by law, which are somehow (directly or indirectly) related to the crime, objects of crime, tools and means of committing the crime, criminally obtained property, dangerous and harmful items, etc.). These are Belgium, the Republic of Korea, the Netherlands, Japan (Kozachenko and Zinevych, 2015).

\section{Legal nature of special confiscation}

According to the current criminal legislation of Ukraine, special confiscation consists in the forced gratuitous confiscation of money, valuables, and other property by a court decision in the cases specified by this Code, subject to the commission of an intentional crime or socially dangerous act falling under the provisions of the Special part of this Code, for which the main punishment in the form of imprisonment or a fine of more than three thousand non-taxable minimum incomes.

In accordance with Part 2 of Art. 96-2 of the Criminal Code of Ukraine, if the money, valuables, and other property referred to in paragraph 1 of part one of this article, were fully or partially converted into other property, special confiscation is subject to fully or partially converted property. If the confiscation of money, valuables and other property referred to in paragraph 1 of part one of this article, at the time of the court's decision on special confiscation is impossible due to their use or impossibility of separation from legally acquired property, or alienation, or for other reasons, the court makes decision on the confiscation of a sum of money corresponding to the value of such property.

In addition to confiscation of money, valuables and other property from a person who committed an intentional crime or socially dangerous act (Part 1 of Article 96-1 of the Criminal Code of Ukraine), the content of special confiscation also includes confiscation of money, valuables and other property from a third party (Part 4 Article 96-2 of the Criminal Code of Ukraine) and confiscation of property withdrawn from civil circulation (Part 3 of Article 96-1 of the Criminal Code of Ukraine). 
Thus, the essence of special confiscation, as another measure of criminal law nature, is the forced and gratuitous confiscation of property. Property (money, valuables) is confiscated in cases specified by the Criminal Code of Ukraine, provided that the person commits an intentional crime or a socially dangerous act that falls under the signs of a crime.

That is, such a person can be: either a subject of a crime, or a person who does not have the characteristics of a subject of a crime (a person who has not reached the age of criminal responsibility or an insane person).

Based on the above, we can identify those signs of special confiscation, which characterize it as a measure of criminal law.

First, special confiscation consists in the forcible confiscation of property, i.e. such property is confiscated against the will of the person. Seizure of property in case of special confiscation is free of charge, which means that the person does not receive any compensation.

In addition, the seized property becomes the property of the state, i.e. the further fate of the seized property is decided by the state. It is the state that has the right to decide the future fate of such property: to send it to the state budget or, for example, to transfer it to the fund for assistance to victims of crime.

The subject of special confiscation, as seen from the text of the legislative provisions of Art. 96 -1 and Art. 96-2 of the Criminal Code of Ukraine may be:

1) property obtained as a result of a crime (or acts that contain elements of a crime);

2) property that was intended (used) to persuade a person to commit a crime, to finance and / or materially support a crime or to reward it for its commission.

3) means or instruments of committing a crime that have been found, manufactured, adapted or used to commit a crime, except for those that are returned to the rightful owner.

It should be noted that to denote the subject of special confiscation, the legislator uses not only the concept of property, but also the phrases "money, valuables" and the concept of "other property". Thus, the scope of special confiscation is not limited to certain things of the material world or their totality, but also extends to property rights. This is due to the provisions of Part 1 of Art. 190 of the Civil Code of Ukraine, according to which property as a special object is a separate thing, a set of things, as well as property rights and obligations (Verkhovna Rada, 2003). In addition, under Article 2 (d) (d) of the UN Convention against Corruption, "property" means any assets, tangible or intangible, as well as legal documents or assets proving ownership of such assets, or their interests (United Nations, 2003). 
An important feature of property as a subject of special confiscation, which essentially distinguishes the latter from confiscation of property as punishment is the connection of such property with the crime (or actions of a person containing signs of crimes under the relevant articles of the Special Part of the Criminal Code of Ukraine) (Vynnyk, 2016). Legal analysis of Art. 96-1 and Art. 96-2 of the Criminal Code of Ukraine makes it possible to say that the connection of the subject of special confiscation with the crime is manifested in four ways, in particular:

1) money, valuables and other property obtained as a result of the crime and / or income from such property.

2) were intended or used to persuade a person to commit a crime, to finance and / or provide material support for a crime or to reward it.

3) were the subject of a crime, except for those returned to the rightful owner.

4) have been found, manufactured, adapted, or used as means or instruments of committing a crime, except for those returned to the rightful owner.

Money, valuables, and other property are also subject to confiscation if they were the subject of a crime and must be returned to the owner. Thus, the legislator establishes an important provision that the object of the crime (money, valuables, other property) is always returned to the rightful owner. In case the owner can't be found, the property becomes the property of the state. Such a change in the legal nature of the seizure of property from special confiscation to the transfer of state ownership has the effect of leaving the owner a legal opportunity to demand the return of this property in civil law (Melnyk and Khavronyuk, 2007).

The next essential feature of special confiscation is the possibility of its appointment by a decision or ruling of the court. At the same time, this property of special confiscation refers to the order of appointment of this measure rather than expresses its essence.

From the legislative definition of special confiscation directly follows its feature as a warning, non-punitive nature of the latter. Special confiscation is essentially a measure of influence on a person who has committed a crime or socially dangerous act provided by the Criminal Code of Ukraine, which aims not to restrict the rights or freedoms, but to stop criminal activity, restore social justice and prevent new crimes.

The above properties of special confiscation make it possible to argue that it is a criminal measure of influence by the state on the person who committed the crime, and therefore it justifiably finds its place in the system of criminal law (Trinchera, 2020). The content of this measure is to take away from the person and withdraw from the state revenue all the 


\section{Special Confiscation as a Measure of Criminal Law under Ukrainian Legislation}

benefits and material values received from the crime, regardless of their transformation, which in turn makes the crime unprofitable for the person, deprives him or her of the opportunity to receive from it any material benefits. Given that the property confiscated from a person by special confiscation is criminal in nature, it is impossible to speak of deprivation or restriction of such a person's property rights, and therefore there is no element of suffering of a person from such seizure.

That is, special confiscation is justifiably placed by the legislator in the system of non-punitive measures of criminal law influence and is defined as a measure of criminal law nature (Minyazeva, 2019).

The above makes it possible to formulate the definition of the concept of special confiscation as a coercive, gratuitous measure of a criminal nature, which is applied to a person for intentionally committing a socially dangerous act under the Criminal Code of Ukraine. The aim of such measure is to deprive a person of any property benefits obtained as a result of the commission of a crime (regardless of the transformations that have undergone these benefits). Special confiscation aims to stop a person's criminal activity, restore social justice and prevent the commission of new crimes.

Special confiscation is a non-punitive measure of criminal law, and therefore its regulation should not be limited to procedural rules, which are a secondary regulator of public relations and provide rules and procedures for implementing substantive law. From the point of view of the criminallegal essence of special confiscation, its main purpose is not related to the provision of material evidence in criminal proceedings (Polyakov, 2016), while in the criminal procedural aspect special confiscation by its legal nature is one of the ways to resolve the role of material evidence.

\section{Types of special confiscation}

Given the recent changes in the criminal legislation of Ukraine, special confiscation as a criminal measure can be divided into special confiscation, defined by the General Part of the Criminal Code of Ukraine and special confiscation, which is provided in the Special Part of the Criminal Code of Ukraine.

The special confiscation provided for in the General Part of the Criminal Code of Ukraine consists in the forced free confiscation of money, valuables and other property by a court decision in cases specified by the Criminal Code of Ukraine, subject to the commission of a crime under Article 354 and Articles 364, 364-1, $365-2,368-369-2$ of Section XVII of the Special Part of the Criminal Code of Ukraine, or a socially dangerous act that falls under the signs of an act provided for in these articles. 
Special confiscation provided for in the Special Part of the Criminal Code of Ukraine is a set of techniques and methods of criminal influence, which is applied by the court at the same time as sentencing, to the person who committed the crime (criminal offense), in order to prevent future acts.

This type differs from the previous type of special confiscation by the following:

1) this measure is applied only on condition of commission of a crime (criminal misdemeanor) and at commission of objectively illegal act.

2) the subject of application is exclusively a convicted person, in contrast to the special confiscation defined in the General Part of the Criminal Code of Ukraine where the subjects are also the suspect, accused and other persons who perform various procedural roles.

3) the subject of special confiscation provided for by the Special Part of the Criminal Code of Ukraine may be not only money, valuables, or other property, but also items that do not have some features of property.

4) the specified confiscation is applied exclusively by a court verdict, which excludes the possibility of registration by other procedural decisions.

5) in contrast to a similar criminal law measure provided for in the General Part of the Criminal Code of Ukraine, this measure may be applied on both dispositive and imperative grounds, depending on whether the legislator recognizes special confiscation mandatory or grants the court the right, taking into account the circumstances crime and the specifics of the subject of special confiscation, to decide on the application of special confiscation at its discretion (Kozachenko and Zinevych, 2015).

\section{Differences between confiscation and special confiscation}

By legal (legal) nature, general confiscation is provided by Art. 59 of the Criminal Code of Ukraine and is a type of additional punishment (see Part 2 of Article 52 of the Criminal Code of Ukraine), which is part of the system of penalties provided by the Criminal Code of Ukraine. By its nature and specifics of restrictions on the rights and freedoms of the convict, confiscation of property belongs to the group of property penalties such as fines, correctional labor, service restrictions for servicemen. Confiscation of property is a means of state coercion applied by a court sentence to a person who has committed a crime and meets the criteria of criminal punishment, namely: 


\section{Tetiana Nikolaienko, Viktoria Babanina y Tetiana Bohdanevych \\ 836 Special Confiscation as a Measure of Criminal Law under Ukrainian Legislation}

1) is appointed only for the crime committed by a court sentence.

2) is a punishment for a crime committed and causes the convict certain suffering, restrictions.

3) included in the exhaustive list of types of punishment (Polyakov, 2016).

As for special confiscation (Article 96-1 of the Criminal Code of Ukraine), by its legal nature it refers to other (than punishment) measures of criminal law nature, as it is not included in the list of punishments (Article 51 of the Criminal Code of Ukraine).

Thus, at first glance, the basic difference between confiscation of property as punishment and special confiscation as another measure of a criminal law nature is that these two measures of influence are different in their legal nature. The first is an additional type of criminal punishment, which is enshrined in the rules of criminal law, has its own specific features in the system of additional punishments and features of application. While special confiscation is not a criminal punishment but refers to other measures of a criminal law nature and has its own specific features (Munoz, 2019).

However, the difference between these measures is confirmed not only by the location of the rules governing these two categories, but also by the features that characterize them and determine their content. Thus, confiscation of property as an additional type of criminal punishment has the following features:

1) seizure of property from a person who has committed a crime and is the subject of a crime.

2) the property of a person convicted of a crime is confiscated, i.e., despite the will of the convict.

3) such seizure is gratuitous, i.e., the convict is not compensated in any way for the seized property (some scholars also attribute the finality of seizure of such property to the signs of confiscation of property as punishment).

4) only property owned by the convicted person is confiscated, including his or her share in joint ownership, as well as shares, deposits of the convict in a bank, etc. (Yatsenko, 2002). Replacement of confiscated property for an equivalent amount of money is not allowed (Melnyk and Khavronyuk, 2007).

5) the property to be confiscated becomes the property of the state, i.e. the further fate of the confiscated property is decided by the authorized state bodies. 
As for the special confiscation of property (Article 96-1 of the Criminal Code of Ukraine), it is also characterized by such features as confiscation of property, i.e. its seizure from a person who is forced and gratuitous. At the same time, the property related to the crime is confiscated from the person. That is, the main difference is that when applying confiscation of property as a form of punishment, the property is the property of the guilty person, and therefore, such a person legally owns such property. Whereas, in the case of special confiscation, the property to be confiscated is not the property of the person in whose possession it was, the person has no rights to such property.

It should be noted that in the case of general confiscation, property is confiscated from the subject of the crime, who is found guilty by a court conviction, and the sanction of a crime committed by such a person provides directly or optionally the possibility of confiscating such property.

That is, confiscation of property (Article 59 of the Criminal Code of Ukraine) can be ordered only on the basis of a court conviction and only in cases clearly defined by law. In this case, based on the interpretation of the provisions of Art. 98 of the Criminal Code of Ukraine confiscation cannot be applied to minors (Melnyk and Khavronyuk, 2007), i.e. to persons who have not reached the age of criminal responsibility.

Instead, the application of special confiscation is not limited to a court decision in a case. According to the provisions of Part 2 of Art. 96-2 of the Criminal Code of Ukraine, it may be applied on the basis of:

1) a court conviction.

2) court rulings on the release of a person from criminal liability.

3) court rulings on the application of medical measures.

4) court rulings on the application of coercive measures of an educational nature.

In addition, as a type of additional punishment, confiscation of property applies only to the subject of the crime, i.e. such a person must meet all the characteristics of the subject of the crime, as required by criminal law. As for the special confiscation, it can be applied both to the subject of the crime and to other persons. Special confiscation applies to:

1) a person who is not subject to criminal liability in connection with reaching the age from which he may come.

2) an insane person.

3) a person who is released from criminal liability or punishment on the grounds provided by the Criminal Code of Ukraine, except in cases of exemption from criminal liability in connection with the expiration of the statute of limitations. 
4) a third party (Part 4 of Article 96-2 of the Criminal Code of Ukraine).

As can be seen from the analysis of the above legislative provisions, special confiscation applies to a fairly wide range of persons related to the objects of confiscation. This approach of the legislator confirms the thesis about the possibility of applying certain measures to influence not only the identity of the offender, but also others. It must be acknowledged that the legislator clearly lists these persons, defining their features and, thus, limiting the spread of special confiscation to other persons. Thus, it can be argued that the range of persons to whom special confiscation applies is much wider than the confiscation of property, which applies only to the subject of the crime (Sagrado, 2019).

The next distinguishing feature of confiscation of property (Article 59 of the Criminal Code of Ukraine) and special confiscation (Article 96-1 of the Criminal Code of Ukraine) are the purposes of their application. Indeed, the use of confiscation of property as an additional type of punishment, as follows from the text of Art. 59 of the Criminal Code of Ukraine, aims not only at punishment, but also at correction of the convict, and also prevention of commission of new crimes both by the convict, and other persons. That is, confiscation of property as a form of punishment pursues such a goal as:

1) punishment (its main purpose - the restoration of social justice) (Moskovoy, 2011). By its nature, punishment has a repressive nature (intimidation, retribution for a crime);

2) correction, i.e. such changes in the convict's personality when he is deprived of negative traits and attitudes that can lead to readiness for socially dangerous and illegal behavior, and encourage proper behavior, respect for the rules and traditions of human coexistence (Melnyk and Khavronyuk, 2007);

3) prevention of committing a new crime by convicts. In science, such actions are called "special prevention", which means the desire of the legislator to warn the person about the inadmissibility of criminal behavior in the future, i.e. special prevention is aimed directly at the person of the offender;

4) prevention of crimes by other persons (general prevention), aimed at deterring others from committing crimes by punishing a particular person (Fesenko, 2012).

In turn, special confiscation plays a precautionary role, aimed at stopping a person from committing a crime, preventing him from committing new crimes and restoring social justice. Thus, the seizure of any material property obtained as a result of a crime, i.e. property acquired by criminal means, not only makes the commission of such a crime unprofitable for a person, but to some extent restores social justice. Confiscation of weapons 
or means obtained as a result of a crime or simply used for the purpose of committing a crime deprives a person of the opportunity to commit new crimes. It should be emphasized that the deprivation of a person of property by special confiscation cannot be considered to contain elements of punishment. The right to such property does not penetrate into a person, and therefore it is impossible to speak about deprivation or restriction of the property right of such person. That is, the purpose of special confiscation is to stop a person's criminal activity, restore social justice and prevent the commission of new crimes.

The next criterion for distinguishing between special confiscation and confiscation of property as a type of punishment is the conditions of application of these measures.

In particular, as a type of additional punishment, confiscation of property is imposed for the commission of serious and especially serious mercenary crimes, as well as for crimes against the foundations of national security of Ukraine and public safety, regardless of their severity. That is, confiscation of property is applied only in cases specifically provided for in the sanction of the article of the Special Part of the Criminal Code of Ukraine, which provides for a crime for which a person is prosecuted.

As for special confiscation, the latter is used not only for the commission of crimes by a person, but also socially dangerous acts that are not a crime. Thus, the legislator in Art. 96-1 of the Criminal Code of Ukraine clearly defines for which crimes or acts that fall under the signs of a crime under the Special Part of the Criminal Code of Ukraine, confiscation is applied to a person as another measure of a criminal nature.

Confiscation of property as a punishment and special confiscation as another type of criminal law also differ in the consequences of their use. As an additional type of punishment, confiscation of property cannot be applied independently, it is always attached to the main punishment. With the application of punishment, a person acquires the status of a criminal record.

In its content, a criminal record is a legal status of a person that arises in connection with his or her conviction to criminal punishment and under the conditions specified in the law is characterized by the occurrence of such consequences for such a person, negative for him or her (Skead et al., 2019). As for the special confiscation of property, its application does not entail such a legal consequence as a criminal record, because in essence special confiscation is a non-punitive measure of criminal influence.

As we can see, by their nature confiscation of property and special confiscation are different legal phenomena, which ideologically have their own significance within the norms of criminal law, in science and in law enforcement practice. 
Tetiana Nikolaienko, Viktoria Babanina y Tetiana Bohdanevych
840 Special Confiscation as a Measure of Criminal Law under Ukrainian Legislation

\section{Conclusions}

The study revealed the differences between confiscation and special confiscation, identified the essential differences and substantive features of each of these institutions and draw the following conclusions:

1. Confiscation of property (Article 59 of the Criminal Code of Ukraine) and special confiscation (Article 961 of the Criminal Code of Ukraine), although they have some common features are independent institutions of criminal law, which have their own special characteristics.

2. They are different in legal nature. Confiscation of property is a type of additional punishment, and special confiscation of property is an independent type of other measures of a criminal law nature.

3. As well as confiscation of property, special confiscation in some cases can be a form of criminal liability and is used only by court decision.

4. The main difference between the investigated institutions is that their application seizes property of different nature, namely: the subject of confiscation of property in accordance with Art. 59 of the Criminal Code of Ukraine is property that belongs to the convict on the right of ownership, instead of applying Art. Art. 96-1 and 96-2 of the Criminal Code of Ukraine, property related to the commission of a crime is subject to confiscation.

5. A feature of special confiscation is the possibility of its application not only to a person who has committed a crime or socially dangerous act, but also to a third party, while no other criminal law measure can be applied to a third party. That is, special confiscation may act as a criminal measure, which restricts the property rights of both the convict and third parties, but only in the part relating to the confiscation of property in the illegal possession of a person.

6. Exceptional grounds for special confiscation under Part 2 of Art. 96-1 of the Criminal Code of Ukraine are: 1) a court conviction; 2) court decision on release of a person from criminal liability; 3) court decision on the application of coercive measures of a medical nature; 4) court decision on the application of coercive measures of an educational nature.

7. The peculiarity of special confiscation is that in some cases special confiscation is a form of criminal liability. At the same time, the application of other measures of a criminal law nature is not a responsibility but is a measure of the state's response to acts of socially dangerous or harmful to society. 
8. The appeal of confiscated property to the state is set by the legislator in connection with such a priority measure as compensation for the damage caused to the victim.

\section{Bibliographic References}

BIDNA, Oksana. 2017. "The concept of confiscation as a form of punishment" In: Scientific Bulletin of Kherson State University. Series: Legal Sciences. Vol. 3, No. 6, pp. 57-61.

FESENKO, Elizaveta. 2012. Comments on Art. 50 of the Criminal Code of Ukraine. A.S.K. Kiev, Ukraine.

GRIGORIEVA, Lyudmila; PAVLOVSKAYA, Svitlana. 2014. Application by courts of the legislation on the property right at consideration of civil cases. Istina. Kyiv, Ukraine.

KOZACHENKO, Oleksandr; ZINECYCH, Andriy. 2015. "Types of confiscations under the criminal law of Ukraine" In: Latest criminal law research. No. 7, pp. 47-51.

LIPINSKY, Dmytriy; MUSATKINA, Alexandra. 2019. "Problems of compliance of Russian anti-corruption legislation with international corruption standards" In: Vestnik of Saint Petersburg University-Law-Vestnik Sankt-Peterburgskogo Universiteta-Pravo. Vol. 4, No. 10, pp. 673-69o.

MELNYK, Mykola; KHAVRONYUK, Mykola. 2007. Scientific and practical commentary to the Criminal Code of Ukraine. Legal Thought. Kyiv, Ukraine.

MINYAZEVA, Tetyana. 2019. "Other measures of criminal character in the Russian Federation and the Republic of Korea" In: Pravo - Tomsk State University Journal of Law. No. 31, pp. 100-111.

MOSKOVOY, Viktor. 2011. "Confiscation of property as another measure of a criminal law nature. Some problems of theory and legislative consolidation” In: Law and politics. No. 9, pp. 117-123.

MUNOZ, Carolina. 2019. "The confiscation of property, material profits and proceeds of crime" In: Revista juridica de castilla y leon. No. 48, pp. 87127.

POLYAKOV, Viktor. 2016. "Legal nature of confiscation in the legislation of Ukraine: substantive and comparative legal analysis" In: National Legal Journal: theory and practice. No. 17, pp. 131-135. 
Tetiana Nikolaienko, Viktoria Babanina y Tetiana Bohdanevych

842 Special Confiscation as a Measure of Criminal Law under Ukrainian Legislation

PONOMARENKO, Yuriy. 2009. Types of punishments under the criminal law of Ukraine. Finn. Kharkiv, Ukraine.

SAGRADO, Oscar. 2019. "Confiscation in the investigation and prosecution of the money laundering crime”. In: Revista general de derecho penal. No. 31. Article Number: 421354.

SKEAD, Natalie; TULICH, Tamara; MURRAY, Sarah; TUBEX, Hilde. 2019. "Reforming proceeds of crime legislation: Political reality or pipedream?" In: Alternative law journal. Vol. 3, No.44, pp. 176-181.

SKRYPNYK, Volodymyr. 2010. "Confiscation as a basis for termination of ownership”. In: Entrepreneurship, Economy and Law. Vol. 4, pp. 79-88.

SOBKO, Ganna. 2008. Confiscation under the criminal legislation of Ukraine. Abstract of PhD Thesis. National Academy of Sciences of Ukraine, Institute of State and Law named after Koretsky. Kyiv, Ukraine.

TAGANTSEV, Nikolay. 2001. "Russian criminal law. General part". Autograph. Tula, Russia.

TRINCHERA, Tommaso. 2020. "Confiscation and asset recovery: better tools to fight bribery and corruption crime" In: Criminal law forum. Vol. 1, No. 31, pp. 49-79.

UNITED NATIONS. 2003. United Nations Convention against Corruption of October 31, 2003. Available online. In: https://www.unodc.org/ documents/treaties/UNCAC/Publications/Convention/o8-50026_E. pdf. Consultation date: 12/05/2020.

VERKHOVNA RADA OF UKRAINE. 1984. Administrative Code of Ukraine: Law of USSR of December 7, 1984. Available online. In: https://zakon. rada.gov.ua/laws/show/80731-10?lang=en\#Text. Consultation date: 12/05/2020.

VERKHOVNA RADA OF UKRAINE. 2001. Criminal Code of Ukraine: Law of Ukraine of April 5, 2001. Available online. In: https://zakon.rada.gov. ua/laws/show/2341-14 Consultation date: 12/05/2020.

VERKHOVNA RADA OF UKRAINE. 2003. Civil Code of Ukraine: Law of Ukraine of January 16, 2003. Available online. In: https://zakon.rada. gov.ua/laws/show/435-15 Consultation date: 12/05/2020.

VERKHOVNA RADA OF UKRAINE. 2004. Civil Procedure Code of Ukraine: Law of Ukraine of March 18, 2004. Available online. In: https://zakon. rada.gov.ua/laws/show/1618-15\#Text Consultation date: 12/05/2020. 
VERKHOVNA RADA OF UKRAINE. 2014. On Amendments to the Criminal and Criminal Procedure Codes of Ukraine regarding the implementation of the Action Plan on visa liberalization by the European Union for Ukraine: Law of Ukraine of April 18, 2014. Available online. In: https:// zakon.rada.gov.ua/laws/show/222-18\#Text. Consultation date: 12/05/2020.

VERKHOVNA RADA OF UKRAINE. 2015. On Amendments to Certain Legislative Acts of Ukraine Concerning Ensuring the Activities of the National Anti-Corruption Bureau of Ukraine and the National Agency for the Prevention of Corruption: Law of Ukraine of February 12, 2015. Available online. In: https://zakon.rada.gov.ua/laws/show/198-19\#Text Consultation date: 12/05/2020.

VYNNYK, Anna. 2016. "Legal nature of property that is subject to special confiscation under the Criminal Code of Ukraine" In: Current problems of improving the current legislation of Ukraine. No. 42, pp. 147-156.

WASSMER, Martin. 2019. "The latest Criminal Law reforms in the General and Special Part of the German Criminal Code" In: Pravo. No.3, pp. 203-220.

YATSENKO, Stanislav. 2002. Scientific and practical commentary to the Criminal Code of Ukraine. A.S. K. Kyiv, Ukraine.

YUSHCHYK, Olena. 2014. "The content of punishment". In: Scientific Bulletin of Uzhhorod National University. Series: Law. No. 26, pp. 238-242.

CONSTITUTION OF UKRAINE. 1996. On June 28. Available online. In: https:// zakon.rada.gov.ua/laws/show/254\%Do\%BA/96-\%Do\%B2\%D1\% 80\#Text. Consultation date: 15/04/2020. 

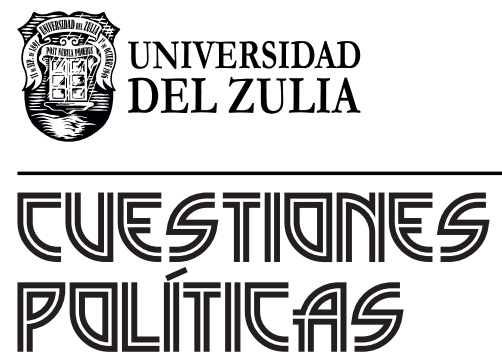

Vol.39 No 68

Esta revista fue editada en formato digital y publicada en enero de 2021, por el Fondo Editorial Serbiluz, Universidad del Zulia. Maracaibo-Venezuela 